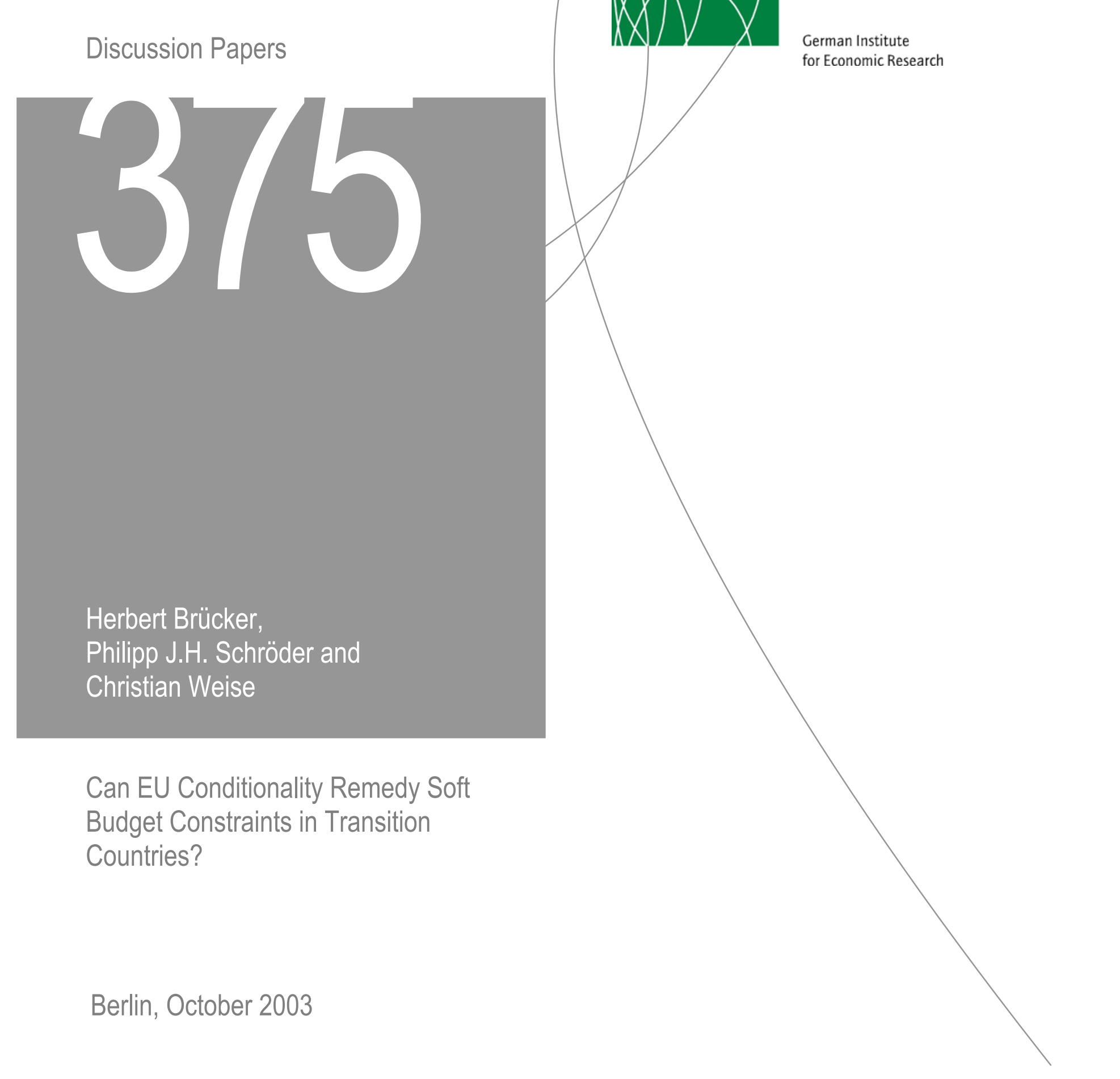


Opinions expressed in this paper are those of the author and do not necessarily reflect views of the Institute.

DIW Berlin

German Institute

for Economic Research

Königin-Luise-Str. 5

14195 Berlin,

Germany

Phone +49-30-897 89-0

Fax $\quad+49-30-89789-200$

www.diw.de

ISSN 1619-4535 


\title{
Can EU Conditionality Remedy Soft Budget Constraints in Transition Countries?
}

\author{
Herbert Brücker* Philipp J.H. Schröder ${ }^{\dagger}$ \\ Christian Weise ${ }^{\ddagger}$
}

September 2003

\begin{abstract}
Soft budget constraints (SBCs) are a persistent feature of transition economies and have been blamed for i.a. a lack of fiscal consolidation and sluggish growth. EU eastward enlargement has - among other things - been conditioned on tackling SBCs. This paper analyzes such outside conditionality theoretically and empirically. First, modelling the SBC problem as a war of attrition between the applicant countries' governments and firms we find that outside conditionality can foster SBC hardening. Yet, toughening the EU stance or reducing the number of enlargement rounds may have ambiguous effects. Second, estimating SBC hardening in a partial adjustment model by measuring the reaction of employment to output changes we find that EU conditionality did indeed help candidates to fight SBCs.
\end{abstract}

Key Words: soft budget constraint, EU enlargement, war of attrition. JEL: F15, D78, P21, P26, P30, G30

${ }^{*}$ DIW Berlin and IZA, Bonn.

${ }^{\dagger}$ Aarhus School of Business, Denmark, and DIW Berlin.

${ }^{\ddagger}$ European Commission, Brussels.

This article represents only the views of the authors, not those of the European Commission or any other institution.

Acknowledgments: This paper benefited substantially from the comments of an anonymous referee and from discussion with Thomas Apolte, Gérard Duchêne, Paul Gregory and the participants at the R.O.S.E.S. Seminar on Enlargement Economics, Paris 2003, and the participants of the annual meeting of the department for institutional economics and comparative economic systems of the German Economic Association Kühtai, 2002. The excellent research assistance of Kenan Šehović is gratefully acknowledged. The authors alone are responsible for any remaining errors.

Corresponding author: Philipp J.H. Schröder, Aarhus School of Business, Fuglesangs Allé 4, DK-8210 Aarhus V, Denmark, Tel.:+45 89486392, Fax:+45 89486125, psc@asb.dk. 


\title{
Can EU Conditionality Remedy Soft Budget Constraints in Transition Countries?
}

\begin{abstract}
Soft budget constraints (SBCs) are a persistent feature of transition economies and have been blamed for i.a. a lack of fiscal consolidation and sluggish growth. EU eastward enlargement has among other things - been conditioned on tackling SBCs. This paper analyzes such outside conditionality theoretically and empirically. First, modelling the SBC problem as a war of attrition between the applicant countries' governments and firms we find that outside conditionality can foster SBC hardening. Yet, toughening the EU stance or reducing the number of enlargement rounds may have ambiguous effects. Second, estimating SBC hardening in a partial adjustment model by measuring the reaction of employment to output changes we find that EU conditionality did indeed help candidates to fight SBCs.
\end{abstract}

Key Words: soft budget constraint, EU enlargement, war of attrition. JEL: F15, D78, P21, P26, P30, G30

\section{Introduction}

The problem of soft budget constraints (SBCs) - the lack of financial discipline at the firm level, whether state or privately owned - remains a persistent feature of many transition economies (e.g. Kornai, Maskin, Roland 2003; Kornai, 2001; EBRD, 1999, ch.7). Yet in view of the progressing eastward enlargement of the European Union, many observers have concluded that since future membership is conditional on a series of key economic and institutional performance measures, problems inherited from the socialist past such as SBCs would be overcome. ${ }^{1}$ For example, the EBRD (2001) comments:

\footnotetext{
${ }^{1}$ Obviously this supposed beneficial impact from outside conditionality arises for a number of economic problems and from the conditionalities imposed by a host of institutions. For example, Perotti (1998: 1706) notes: “(...) there is a clear benefit in the commitment value created by international institutions with a reputation for tough lending criteria such as the IMF and the World Bank."
} 
"It is therefore important to recognise that international integration can complement domestic factors in advancing reforms and in strengthening economic performance. The EU accession process has been a strong influence on the direction and pace of reform for the ten candidate countries (...), and this has helped to counter the influence of domestic vested interests."

(EBRD, 2001: 11)

The conditionality imposed by the existing EU member states on applicants from Central and Eastern Europe ${ }^{2}$ is most prominent in the Copenhagen Criteria. These criteria outline conditions which the applicants have to fulfill for later membership to become feasible. The European Council meeting in Copenhagen, June 1993, introduced the criteria under the phrase 'conditional acceptance of eventual membership'. The following three toplevel conditions were announced: (i) Stable institutions guaranteeing democracy, rule of law, human and minority rights. (ii) Existence of a functioning market economy. Capacity to cope with the competitive pressures and market forces within the Union. (iii) Ability to adopt and implement the acquis communautaire and adherence to the aims of political, economic, and monetary union. The second and third criteria have a clear linkage to economic policy in the applicant countries. Particular relevant in the context of the present discussion is the demand for 'adherence to the aims of ... economic and monetary union', which evokes the fulfilment of the Maastricht criteria with the well known fiscal deficit and government debt limits, hence a strict ceiling on conceivable state transfers to firms. Moreover, the acquis communautaire requires i.a. that the rules of European competition policy and industrial policy be implemented, which restrict the payment of subsidies to loss-making enterprises. Finally, in practice, the monitoring of state aid practices (EU Treaty - Article 87) and financial sector reform in the applicant countries were key elements of the enlargement process.

Since the 'Agenda 2000', which was drafted in 1997, the European Commission has produced regular progress reports on the applicant countries. Encompassing a host of topics related to the fulfilment of the Copenhagen Criteria, these reports deal extensively with issues of structural reform. They monitor, in particular, progress in financial sector and banking reform, lend-

\footnotetext{
${ }^{2}$ The status of an accession candidate to the EU was granted to Bulgaria, Czech Republic, Estonia, Hungary, Latvia, Lithuania, Poland, Romania, Slovakia and Slovenia among the transition countries. In addition, Cyprus, Malta and Turkey belong to the group of accession candidates. With the exception of Bulgaria and Romania all accession candidate countries from Central and Eastern Europe will join the EU in 2004, and Bulgaria and Romania may enter the EU in another enlargement round in 2007.
} 
ing practices, state-to-enterprise relations and firm restructuring. These items have clear implications for the existence or rather removal of SBCs. For example, the 2000 progress report for Lithuania remarks:

"Another factor that hinders in-depth restructuring is the lenient financial discipline in enterprises, which is caused by a slow enforcement of bankruptcy procedures and the existence of soft budget constraints."

(European Commission, 2000: 69)

Furthermore, the Commission's emphasis on banking sector reform and the decentralization and privatization of state banks ${ }^{3}$ is fully in line with one of the prominent remedies to the SBC problem that emerges from the seminal Dewatripont and Maskin (1995) formulation of the SBC phenomenon; namely, the decentralization of credit as the key element of institutional reform necessary to impose financial discipline on firms. However, it is an open question whether and to what degree the conditionality of the EU is indeed enforced in the enlargement process. For example, the strong political backing which was provided by Greece to Cyprus or by Germany to Poland made it unlikely that these countries could have failed, even if they would had not implemented the acquis communautaire completely. ${ }^{4}$

In this paper we use EU eastward enlargement with its membership conditions to study - both theoretically and empirically - the mechanics and effectiveness of such outside conditionality on removing SBCs. How and when does such outside conditionality actually help the applicant country to conduct the shift towards a regime with institutions enforcing hard budget constraints?

In the theoretical section, we model the issue of SBCs and outside conditionality as a game between the national governments and firms. The government aims for and benefits from hard budget constraints (HBCs) but is unable to enforce such a policy against the will of the firms, as firms - for which the SBC can be viewed as a no-cost insurance against financial problems or indeed an ex post negotiated subsidy - maintain the power to block

\footnotetext{
${ }^{3}$ For example, the 1998 progress report for the Czech Republic reads "Significant problems still remain in the financial sector, especially in the banking sector, which suffers from an acute problem of bad loans. In order to create a sound and competitive banking sector, the remaining state-owned banks need to be privatised." (European Commission, 1998: 25)

${ }^{4}$ It is noteworthy, however, that the only two applicants that received explicit comments on persisting SBC problems in the decisive 2002 progress reports were Bulgaria and Romania (see European Commission, 2002a: ch 2.3, p.44 and European Commission, 2002b: ch 2.3, p.42, respectively), the two countries that have not been allowed to join the EU in 2004.
} 
any reform. ${ }^{5}$ Further, both players would benefit from EU membership, but only the government can lead the negotiations, i.e. only it has the power to submit and push or to postpone and delay the country's membership application. Hence the players can hold each other hostage, and a war of attrition unfolds. In this waiting game - in the spirit of Alesina and Drazen (1991) the firms hope for the government to push for membership to the EU even though the SBC issue is unresolved, while the government may delay application hoping for firms to tighten their budgets, citing EU membership conditions as its justification. The game is won by the player willing to wait the longest for his favorite outcome to materialise. In this setting we find that once the outside institution (EU) imposes a tough conditionality demanding HBCs, the game does change in favor of the government, hence EU conditionality can remedy the SBC problem by solving part of the dynamic commitment problem. We also introduce uncertainty with regard to the type of EU, i.e. whether the EU will admit countries with SBCs, and discuss also a number of scenarios in which the outside conditionality may or may not help to harden SBCs.

In the empirical part of this paper, we examine whether obtaining the candidate status in the EU enlargement process corresponds to a regime shift towards HBCs. Since the degree of SBC hardening is difficult to measure directly, we build our empirical investigation on an indirect measure, namely, the adjustment of employment to changes in demand and output. In a first step, we formalise the idea that, under SBCs, firms display a higher labourto-output ratio and a slower adjustment of employment to outside shocks. In the second step, we derive from our theoretical considerations a simple partial adjustment model which forms the basis for our econometric analysis. We obtain the following empirical results: Countries which possess a candidate status yields both a lower labour-to-output ratio in the long run and a higher speed of adjustment of employment to output shocks relative to countries which do not. We observe significant differences in economic behaviour both before and after the candidate status was granted within the sample of the (later) candidate countries, as well as between the candidate countries and the transition countries outside the circle of the EU applicants. Thus we find in our empirical part evidence that the status of an accession candidate to the EU has indeed changed economic behaviour in the direction towards HBCs.

Section 2 recaps central developments in the SBC literature and places the present paper in this context. Section 3 introduces the model, and exam-

\footnotetext{
${ }^{5}$ What we envisage here is a policy stalemate, where the status quo rules as long as no consensus between the government and firms forms.
} 
ines the impact from different firm, government and EU parameters on SBC hardening. Section 4 presents empirical evidence on whether the candidate status of transition economies and the associated EU conditionality did indeed have an impact on SBC hardening. Section 5 concludes the paper and presents some policy implications.

\section{SBC theory - main ideas and concepts}

The pioneering work on soft budget constraints in the context of socialist economies and later transition economies has been carried out by Kornai (1979, 1980). ${ }^{6}$ Recent major overviews of the theoretical and empirical literature are given in Kornai, Maskin and Roland (2003), Maskin and Xu (2001), Kornai (2001), Dewatripont and Roland (2000) and Maskin (1999). The SBC syndrome is typically understood as a dynamic commitment problem of some central agent or authority - say the government or a bank - not to bail out firms in financial distress. ${ }^{7}$

The theoretical explanations of SBCs found in the literature take several different angles: The first line of reasoning which is associated with Kornai's initial work $(1979,1980)$ derives the SBC syndrome from paternalistic motives of the government. Schaffer's (1989) early formalization of this principle states that the government repeatedly demands financial discipline at the firm level, but is unable to enforce its demands ex post because of social or political costs and thus ends up bailing out firms. Hence countries are

\footnotetext{
${ }^{6}$ Obviously, SBCs are not confined to socialist or transition economies. For example the 'rescue' of the Philipp Holzman AG organised by the German government in 1999 is certainly an incident which, by most definitions, would qualify as an SBC. Also, the formal stepping stone we apply in our empirical analysis of Section 4 is related to Hillman et al. (1987) who formulate a theory of government bail-outs with no reference to planning or transition economies.

${ }^{7}$ This inability to make dynamic commitments is best illustrated as follows: "Initially, when a BC-enterprise [a firm] is first set up and funded, the prospects for success look good. Moreover, to provide the incentive for hard work - which would increase the probability of success - the S-organization [government or bank] may declare that it will refuse to bail the enterprise out should financial difficulties later arise. But later if the enterprise does get into trouble, the S-organization has no way to enforce that declaration. Furthermore, although the expense entailed in repeated bailouts may be high, the cost of economic and social disruption ensuing from the enterprise's collapse could well be even higher. And so ex post there may be an irresistible force for making the bailouts. Indeed, if the potential disruption from collapse is big enough, both parties will anticipate a continuing sequence of bailouts." (Kornai, Maskin and Roland, 2003, p.13). Furthermore, had the firm believed the initial declaration by the government or bank, it would work harder, perform better and the need for a later bail out would have been less likely to materialized in the first place.
} 
stuck in the SBC status quo. This approach is complemented by political economy type explanations, where the government tolerates an SBC in return for political support, or in order to avoid unemployment (e.g. Shleifer and Vishny, 1994; Hillman et al. 1987). However, these theories do not provide an explanation of the differences in the occurrence of SBCs under different systems, i.e. they do not derive the SBC endogenously within the theoretical framework.

This gap in the SBC literature is closed in a second strand of the literature that follows the seminal paper of Dewatripont and Maskin (1995) in deriving the tension between ex ante intention and ex post behavior from economic principles. In the simplest version of the Dewatripont and Maskin model (see for example Dewatripont and Roland, 2000, and Maskin and Xu, 2001), a bank or the government can finance a number of projects/firms which either are good and quick or bad and slow. The type of the projects is unknown to the financing authority, and slow projects will need to be injected with extra funding at a later stage in order to be completed. Within this setup, refinancing is sequentially optimal and hence also entrepreneurs with bad projects will apply for initial funding. However, once the financial authority has lost all opportunity to refinance - e.g. a decentralized banking sector where each bank is too small to fund more than one project - then bad projects would need to obtain their second dose of funding from a new bank. Yet, since the new bank has no share in the sunk cost of the initial period, it will be unwilling to bring a bad project towards completion. By this token, fewer bad projects will be initialized to begin with, and hard budget constraints will be enforced.

Manifestations of the SBC phenomenon are soft loans, budgetory subsidies, tax arrears, credit arrears, wage arrears, etc. (for a detailed discussion see Section 4). The consequences of SBCs are - apart from the immediate negative impact on allocative efficiency and, related to this, the phenomena of shortages (e.g. Kornai, 1980; Quian, 1994) - a lack of fiscal consolidation, problems of international competitiveness, financial bubbles, a lack of innovation and not least, a negative impact on overall economic growth (e.g. Kornai, 2001; Huang and Xu, 1999; Bai and Wang, 1999; Quian and Xu, 1998).

Several solutions to the SBC problem have been proposed along the lines of the main explanations of SBCs: demonopolisation, devolution (or federalism), financial sector reform, etc. (e.g. Dewatripont and Roland, 2000; Quian and Roland, 1998; Dewatripont and Maskin, 1995). On the other hand, more closely related to the present approach - though not addressing SBCs - are Alesina and Drazen (1991) dealing with fiscal stabilisation, Perotti (1998) dealing with financial sector reform in transition economies and Heinemann 
(2000) examining the strategic effects when creating the EMU. In each of these papers, outside conditionality was able to generate a beneficial impact by dragging the economy out of its status quo. In contrast, a recent paper of Roland and Verdier (2003) on law enforcement in transition countries establishes the counterintuitive result that an accession to the EU without conditionality may increase the probability of overcoming a poor status quo if EU membership is associated with improved access to technologies which support law enforcement.

The present paper complements the existing SBC literature by theoretically and empirically examining the role of outside conditionality on hardening SBCs. We develop and test a framework where the SBC is assumed to exist in the status quo such that the government is repeatedly forced to accept SBCs at the firm level. This can be caused by an underlying mechanism such as soft credits granted by a centralised or state-owned banking sector (Dewatripont and Maskin, 1995) or sheer paternalism in the statefirm relationship (Kornai, 1980; Schaffer, 1989). On its own - without the broader consensus of firms - the government is unable to bring about the shift towards a regime with institutions enforcing HBC. In our theoretical and empirical analysis we then address the following questions: What are the effects of adding outside conditionality into the domestic game between firms and government? When can such outside demands challenge the status $q u o$ and alter the game in favour of hard budget constraints? Has EU conditionality in the enlargement process helped to remedy SBCs in the candidate countries?

\section{A simple model of outside conditionality}

Consider a non-EU country where an SBC problem exists. Even though the government, $g$, benefits from and prefers a state of HBCs, it is unable to enforce this policy due to a dynamic commitment problem. In other words, even though ex ante the government would rather not rescue firms in financial difficulties, because it hopes to induce effort and thus reduce the risk of failure, ex post it finds it in its own best interest to bail out troubled firms. For example this SBC status quo could be caused by an underlying problem of centralised credit (Dewatripont and Maskin, 1995). ${ }^{8}$ Firms, $f$, benefit from SBCs. From their perspective, the SBC can be viewed as a free insurance against unfavorable financial states (Hillman et al., 1987) or as an

\footnotetext{
${ }^{8}$ Alternatively, paternalistic or opportunistic motives of the state (Kornai, 1980; Schaffer, 1989; Shleifer and Vishny, 1994) could be the cause of the status quo.
} 
ex post subsidy, favourable tax break etc. ${ }^{9}$ Modelling the SBC like this in reduced form allows us to obtain a simple enough specification that the issue of outside conditionality can be introduced. Furthermore the core issues of the SBC mechanics and the associated commitment problems are already well understood in the literature (see Section 2). Our focus is on the effects of adding outside conditionality to the SBC setting outlined above. What is crucial to the present analysis is the assumption that any change in regime (SBC or HBC) can only be obtained in consensus between the two players, thus the firms can hold the government hostage and impose the status quo SBC regime onto the government. The idea that the softness can be forced upon a government is embedded in several theories of the SBC (Kornai, Maskin and Roland, 2003, p.8): for example, firms facing financial troubles may simply fail to pay taxes, but the government may also face prohibitive costs in bringing about the liquidation of firms which have failed to pay taxes. ${ }^{10}$ As a result the problem of the SBC persists until it is tackled through the consensus regime change. What we envisage here is a policy stalemate, where the status quo rules as long as no consensus between government and firms forms. By the same token, once the system has arrived at an HBC status quo, the switch back can also only be achieved with a consensus of both parties. ${ }^{11}$ If, as introduced above, the underlying SBC problem is caused by a centralisation of credit (Dewatripont and Maskin, 1995), the necessary regime change enforcing $\mathrm{HBC}$ would be the decentralisation and privatisation of the banking sector. The government desires this regime change but lacks the tools to enforce it against the will of the firms. ${ }^{12}$

\footnotetext{
${ }^{9}$ We have chosen to set up the SBC problem as a conflict between firms and government, even though the SBC transmitting agent may still be the financial sector - either directly, as in the Dewatripont and Maskin (1995) model, or indirectly where the government bails out banks with accumulated bad loans instead of bailing out firms (Dewatripont and Roland, 2000, pp.246).

${ }^{10}$ Furthermore, during the early years of transition, legal systems may not be fit to enforce financial demands from the government. Yet, more commonly, softness may be voluntarily, in the sense that political interests such as avoiding excessive unemployment or too-big-to-fail arguments may make the government opt for an SBC strategy, no matter what threats and punishments it initially has announced.

${ }^{11}$ Accordingly, when an economy displays HBCs, firms might still prefer government support in times of distress, but not be able to get it.

${ }^{12}$ Our separation into two states (SBC or HBC) is of course a stark simplification. As Kornai (1998) points out, SBC and HBC are more a matter of degree of hardness than of well defined static states. Yet, the idea that under certain conditions economies experience regime shifts from one state into another appears to us a useful way of thinking about the issue. One example of such a regime shift are the fundamental changes in the British economy under Margaret Thatcher, which could even be interpreted as a hardening of budget constraints, at least for certain sectors.
} 
The power of firms to maintain the status quo is counterbalanced by the prospect of EU membership, whereby the EU imposes membership conditions concerning the hardening of SBCs. Both players, $g$ and $f$, benefit from EU membership. But only the government can negotiate with the EU, i.e. the government has the power to submit and push or to postpone the membership application for the current enlargement round. Thus, a war of attrition unfolds between $g$ and $f$. The government can attempt, via a delay in the EU membership process, to force firms into a pro-HBC regime shift, while firms can block the regime shift, via their refusal to cooperate, hence exerting pressure to obtain EU membership despite persisting SBCs.

The membership conditions that the EU - as an outside institution has imposed via the Copenhagen criteria include financial micro and macro discipline, ${ }^{13}$ conditionalities that may be enforced to varying degrees. The actual toughness of the outside institution is unknown to both agents. The perceived probability of the EU being soft - allowing the country to enter despite of SBCs - is $p$, the probability that the applicant country is allowed to become a member for political, geographic or other reasons despite persisting SBCs. Note that $p$ can, and most probably does, vary for different candidate countries depending on their political backing in the enlargement process.

In the status quo (SBCs continue and no EU membership), payoffs for $g$ and $f$ alike are normalised to zero. Any change from the status quo commands the following present value payoffs: The gains for $g$ of becoming an EU member are $\alpha$. The government's total benefits associated with HBCs, for example stemming from increased tax revenue and fiscal stabilisation following the removal of SBCs, are $\sigma$. The gains for $f$ from EU membership are $\beta$, e.g. the value of market access to the EU or infrastructure investments following membership. The present value of all costs that firms face when removing SBCs - i.e. the loss of the insurance or subsidy value that the SBCs constitute or the risk of bankruptcy net of the potential efficiency gains from HBCs - is $\tau$. Table 1 summarises the payoffs. All parameters $\alpha, \sigma, \beta, \tau>0$.

Table 1: Payoffs from changes of the status quo

\begin{tabular}{lcc}
\hline \hline & EU membership & HBC regime \\
\hline Government & $\alpha$ & $\sigma$ \\
Firms & $\beta$ & $-\tau$ \\
\hline \hline
\end{tabular}

\footnotetext{
${ }^{13}$ See our discussion of the enlargement process in Section 1.
} 
The sequence of the game is as follows:

- Step zero: EU opens enlargement round and imposes HBC condition.

- Step one: $f$ choose to discipline budgets (HBC) or to maintain the status quo (SBC).

- Step two: $g$ chooses to submit or not to submit a membership application, and

- if the country displays an HBC and a membership application is submitted, the EU accepts the new member with certainty,

- if the country displays an SBC and a membership application is submitted, the EU accepts the new member with probability $p$ (soft EU) or rejects the applicant with probability $1-p$ (hard EU).

- Step three: If $g$ does not submit an application or if the country is rejected on grounds of an SBC, the game starts anew with probability $(1-\phi)$ in the next round.

Thus, the game may end - possibly after some periods of delay - with either EU membership and HBCs or with EU membership and SBCs. Further, if the game starts again from the beginning there is a "closing the door" probability of $0<\phi<1$, i.e. the risk that there will be no further enlargement rounds, and that, hence, the game will end with no membership and continuation of SBCs (the status quo) in the indefinite future. ${ }^{14}$ It also immediately follows that once an HBC is obtained in step one, it will be $g$ 's dominant strategy to submit an application and push for membership, yielding a certain government payoff $\alpha+\sigma$. More importantly, in step two, if a country places an application but is rejected on grounds of an SBC, information on the actual EU type is disclosed - altering the payoffs of the next round. Only $g$ can call forth this action (unveil information). Once the EU type is established to be tough, the game changes into a trivial version where payoffs for firms and government become either zero forever or $\beta-\tau$ and $\alpha+\sigma$ respectively. However, from the government's perspective, forcing the EU to disclose its type bears the risk of the EU turning out to be soft. Hence, the country would enter with persisting SBCs (payoffs $\beta$ and $\alpha$ for firms and government respectively).

It can be noted immediately:

Lemma 1. If $\beta-\tau<0$, then neither a fully credible and committed government nor outside conditionality can enforce a regime shift in favour of

\footnotetext{
${ }^{14}$ Note that the EU has never formally closed enlargement rounds for a country, but has, as the case of Turkey demonstrates, put application requests into cold storage for decades.
} 
$H B C s$.

This says that if the costs of hardening budgets are too high, or if firms do not value EU membership highly, then the government cannot enforce budget discipline, also not via outside conditionality. Hence in the remainder of the paper we assume $\tau<\beta$.

Players discount the future. Payoffs realised in subsequent periods are discounted at the rate of time preference $\rho_{j}, j=g, f$ for the government and firms respectively. This gives a discount factor $\frac{1}{1+\rho_{j}}(1-\phi), j=g, f$, where $(1-\phi)$ is the probability that the game will continue to the next round. Although waiting is costly, the players are willing to wait in order to obtain their favorite outcome, i.e. hoping for the other player to give up. ${ }^{15}$ This war of attrition game is won by the player willing to wait the longest. On this, see Alesina and Drazen (1991) for a version with incomplete information or Hendricks et al. (1988) for a complete information variant.

The favoured outcomes of the two players are: the government wins if HBC discipline is obtained and the country becomes an EU member $(\alpha+\sigma)$. For firms the favoured outcome depends on $p$. For a large enough $p$, the firm wins if the government applies for EU membership even though SBCs persists; membership may or may not result immediately, depending on the EU type. However, for a low $p$, firms and government agree on the best possible outcome, as shown below.

Lemma 2. Firms and government agree on the favoured outcome, namely to switch to an $H B C$ regime and to submit an application, if

$$
p<(\beta-\tau) \frac{\rho_{f}+\phi}{\beta\left(\rho_{f}+\phi\right)+\tau(1-\phi)}
$$

If Lemma 2 is fulfilled the game ends immediately with $\mathrm{HBC}$ and EU membership. ${ }^{16}$ Lemma 2 states that for a strict EU - a low $p$ in the sense of (1) - firms and government will agree on their strategies, and no player will benefit from waiting. Thus in a sense, lemma 2 already answers the question posed by this paper: outside conditionality can remedy the SBC problem.

\footnotetext{
${ }^{15}$ For the government, giving up means submitting an application and pushing for EU membership even though SBCs persist. For firms, it means disciplining the SBC into an HBC.

${ }^{16}$ Lemma 2 is derived by solving the inequality $(\beta-\tau)>p \beta+(1-p)\left(\frac{1-\phi}{1+\rho_{f}}(\beta-\tau)\right)$ for $p$, i.e. the critical $p$ is determined by equating the firms losing payoff $(\beta-\tau)$ with the winning payoff, whereby the winning payoff has a probability $p$ of obtaining EU membership with an $\operatorname{SBC}(\beta)$ and a probability $1-p$ of rejection today and hence a tough EU, such that membership at best can be obtained in the next period with an $\operatorname{HBC}\left(\frac{1-\phi}{1+\rho_{f}}(\beta-\tau)\right)$.
} 
As can be easily intuited, the condition in (1) is less likely to be fulfilled if the costs of hardening SBCs, $\tau$, increases, and if the future means more to firms (i.e. if either $\rho_{f}$ or $\phi$ decrease).

Thus, in terms of policy, one can immediately conclude that the power of outside conditionality is increased when the EU directly compensates the applicant country's firms for the costs of budget disciplining (reducing $\tau$ ), or implements a tough closing-the-door-policy (large $\phi) .{ }^{17}$ In the remainder of this paper we assume that $p$ is larger than the critical value stated in (1). Under this assumption, firm interests and government interests are opposed and hence a war of attrition setting exists.

Two limiting cases complete our basic outline of the model. First consider how the game would change if the EU were fundamentally and credibly committed to strict conditionality. Setting $p=0$, the government action is effectively of no concern to the outcome, and the game is reduced to a simple decision of firms between SBC (payoff: 0) and HBC (payoff: $\beta-\tau$ ). Given lemma 1, EU membership and HBCs will result immediately, since $\beta>\tau$. Second consider the game if there were no EU, i.e. consider a country for which EU membership is no option. Accordingly, by setting $\alpha=\beta=0$, we immediately find that the SBC problem will persist indefinitely.

\subsection{Solution with EU conditionality}

The war of attrition is won by the player willing to wait the longest for his favorite outcome to materialise. If the game is played under complete information - except regarding the type of EU - and using only pure strategies, then there will be no substantial delay. Instead the losing player will give up right away rather than enduring any delay (Hendricks et al., 1988). In settings of incomplete information, the game may feature some delay (Alesina and Drazen, 1991). In either case the winner of the game is determined by the maximum waiting times each player is willing to accept and, hence, by the parameters of the model which affect these waiting times. The maximum willingness of firms to wait is determined by equating the discounted value of winning at time $\bar{t}_{f}$ and the value of giving up immediately:

$$
p \beta\left(\frac{1-\phi}{1+\rho_{f}}\right)^{\bar{t}_{f}}+(1-p)(\beta-\tau)\left(\frac{1-\phi}{1+\rho_{f}}\right)^{\bar{t}_{f}+1}=\beta-\tau
$$

The right-hand side is simply the present value of giving up right away, i.e. implementing HBCs and thus becoming an EU member. The left-hand

\footnotetext{
${ }^{17}$ As a matter of fact, the official position of the EU is that there is no limit on the number of future enlargement rounds $(\phi \rightarrow 0)$ which would, by lemma 2 , weaken the impact of the set conditionality.
} 
side is the present value to the firms of the government applying for EU membership at time $\bar{t}_{f}$ while SBCs persist. The first term is the probability that the country faces a soft EU and actually enters at time $\bar{t}_{f}$ with an SBC times the value from entering with a soft budget. The second term is the probability of facing a hard EU, a fact established only after an unsuccessful application in period $\bar{t}_{f}$, and hence entering in the next enlargement round with an $\mathrm{HBC}$ times the value of entering minus the cost of hardening budgets. From (2) we can solve for the maximum waiting time of the firm:

$$
\bar{t}_{f}=\ln \left(\frac{(\beta-\tau)\left(1+\rho_{f}\right)}{(\beta-\tau)(1-p)(1-\phi)+\beta\left(1+\rho_{f}\right) p}\right) \ln \left(\frac{1-\phi}{1+\rho_{f}}\right)^{-1} .
$$

The government's waiting can be calculated by equating the favorite outcome at time $\bar{t}_{g}$ with giving up immediately:

$$
(\alpha+\sigma)\left(\frac{1-\phi}{1+\rho_{g}}\right)^{\bar{t}_{g}}=p \alpha+(1-p)(\alpha+\sigma)\left(\frac{1-\phi}{1+\rho_{g}}\right)
$$

The left hand side is the value of winning at time $\bar{t}_{g}$, while the right hand side is the value of giving up today, and either becoming an EU member while SBCs persist (payoff $\alpha$ ) with probability $p$ or establishing the type of EU to be hard with probability $1-p$, and hence enforcing HBCs and becoming an EU member in the next round (payoff $\alpha+\sigma$ ). From (4) the maximum waiting time of the government is:

$$
\bar{t}_{g}=\ln \left(\frac{(\alpha+\sigma)(1-p)(1-\phi)+\alpha\left(1+\rho_{g}\right) p}{(\alpha+\sigma)\left(\left(1+\rho_{g}\right)\right.}\right) \ln \left(\frac{1-\phi}{1+\rho_{g}}\right)^{-1}
$$

Due to the sequential nature of the game, when firms are 'tough' i.e. maintain SBCs, then if the government decides to postpone the enlargement negotiation (punish the firms), it can at best achieve its favorite outcome in the next enlargement round. Formally we can state:

Lemma 3. The government wins the game if $\bar{t}_{g}>\bar{t}_{f}+1$, resulting in $H B C s$ and EU membership.

The reasoning of lemma (3) is the common intuition behind the war of attrition where the player that can establish that he is willing to wait longer - either by demonstrating his ability to wait (incomplete information) or because his ability to wait is known (complete information) - wins the game after the second player realises the first one's ability to hold out longer and maximises his payoff by giving up right away (see Bliss and Nalebuff, 1984; Alesina and Drazen, 1991; Hendricks et al., 1988). The basic reasoning of 
lemma (3) can thus be summarised by the function $h=\bar{t}_{g}-\bar{t}_{f}-1$, which, for positive values, says that the government is winning, and for negative values says that the firms are winning. Plugging in (5) and (3) and rewriting gives:

$$
h=\frac{\ln \left(\frac{(1-p)(1-\phi)}{1+\rho_{g}}+\frac{p \alpha}{\alpha+\sigma}\right)}{\ln \left(\frac{1-\phi}{1+\rho_{g}}\right)}+\frac{\ln \left(\frac{(1-p)(1-\phi)}{1+\rho_{f}}+\frac{\beta p}{\beta-\tau}\right)}{\ln \left(\frac{1-\phi}{1+\rho_{f}}\right)}-1
$$

\subsection{Results}

In the following the reaction of $h$ to changes in the various parameters will be examined.

\section{Government and firm parameters}

When differentiating $h$ with respect to the gain, cost and time preference parameters of the two players, we obtain the central war of attrition results. Expressed in terms of the government's chances of winning, we can state:

Proposition 1. The government's maximum waiting time increases relative to the firm's maximum waiting time, i.e. the government's chances of winning - the applicant country joining the EU with an $H B C$ - increase, when:

i) the government's payoff from EU membership, $\alpha$, decreases

ii) the government's payoff from $H B C, \sigma$, increases

iii) the government becomes more patient, i.e. $\rho_{g}$ decreases

iv) the firm's payoff from EU membership, $\beta$, increases

v) the firm's cost from implementing $H B C, \tau$, decrease

vi) the firm become less patient, i.e. $\rho_{f}$ increases.

Proof of these propositions, i.e. the signs for the various derivatives of $h$, as well as of all further results of this model are given in a separate Appendix available from the authors upon request. The results stated in proposition 1 have a clear intuitive interpretation: a government too eager to enter the EU may forgo the beneficial effect of outside conditionality and pressure for EU membership, even though SBCs prevail. Similarly, if the benefits of HBCs for the government become more substantial, its ability to wait for its favorite outcome increases. On the other hand, if firms obtain substantial benefits from EU membership, then their cost of postponement is high and they will 
give up earlier. Conversely, given higher costs of hardening SBCs, firms will be willing to wait longer, hoping for their favorite outcome - membership with SBCs. Finally, patience - as always in the war of attrition - is a good winning strategy.

In terms of policy, proposition 1 ( $i$ ), for example, gives a novel perspective on the strict rejection that several candidate governments voiced in response to the Commission's proposals for watered-down financial support to new members in the future Common Agricultural Policy. In fact this might not be so much a signal to Brussels as to their own firms and economies, namely that the national government is not ready to seek membership at any price, i.e. has the power to wait. Similarly, proposition 1 (ii) could read that the package deal, where the EMU is part of the long-term enlargement project, implies that HBCs become more important for national governments, again strengthening their position vis-à-vis firms. Finally, from proposition 1 (iv) and $(v)$, it follows that if the EU aims at helping candidates to implement a regime shift in favor of $\mathrm{HBCs}$, then increasing the benefits that firms obtain from EU membership (for example reserving full market access to members only) and dampening or compensating the costs resulting from budget hardening and firm restructuring (e.g. the EU financial assistance programs under the Europe Agreements) are sensible policy measures.

\section{Tough versus soft EU conditionality}

The probability of the EU being soft, $p$, and the probability of closing the door, $\phi$, affect both the government's as well as the firms' willingness to wait. Starting with the perceived probability that the country faces a soft EU, the government's maximum waiting may de- or increase with an increase in $p$. In particular, the following result can be stated:

Lemma 4. An increase in the probability, $p$, that the EU is soft will make the government

i) less willing to wait if $\alpha>(\alpha+\sigma) \frac{1-\phi}{1+\rho_{g}}$

ii) more willing to wait if $\alpha<(\alpha+\sigma) \frac{1-\phi}{1+\rho_{g}}$

For proof, see separate Appendix. In case $i$ ) the government's maximum waiting time falls if the probability that the EU is soft increases. In fact, what the condition $\alpha>(\alpha+\sigma) \frac{1-\phi}{1+\rho_{g}}$ says is that losing the game today is worth more than winning it tomorrow. Put differently, the winning-to-losing payoff has such a narrow margin ( $\sigma$ is relatively small) that the government is unwilling to even endure a single round of delay (and the risk of closing 
the door). However, in case $i i$ ) the government will be willing to wait longer if the probability that the $\mathrm{EU}$ is soft increases, since an increase in $p$ means that when the government presses for EU membership to disclose the EU type, it faces the larger risk of entry without having disciplined SBCs. On the other hand, for the firms, we find that $\frac{\partial \bar{t}_{f}}{\partial p}>0$. By speculating on a larger chance of being able to join with an SBC, firms' maximum waiting time always increases as $p$ increases. Thus the overall effect of an increase in $p$ depends on the degree by which the two players' maximum waiting times increase in reaction to an increase in the perceived probability that the EU is soft. To facilitate further comparison, we set the rate of time preference for the two players equal to zero $\left(\rho_{g}=\rho_{f}=0\right)$. There is still discounting in the model, since $\phi>0$.

Proposition 2. Consider the probability level $\hat{p}=1+\frac{\alpha}{2 \sigma}-\frac{\beta}{2 \tau}$ that the EU is of the soft type.

i) If $p>\hat{p}$, then there exists a critical $\phi^{c}, 0<\phi^{c}<1$ such that

(a) for a high risk of closing the door in the sense of $\phi>\phi^{c}$ an increase in $p$ worsens the chance that the government wins;

(b) while for a low risk of closing the door in the sense of $\phi^{c}>\phi$ an increase in $p$ improves the chance that the government wins.

ii) If $p<\hat{p}$, then for any level of $\phi$ an increase in $p$ worsens the chances that the government wins.

For proof see separate Appendix. Proposition 2 says that the generally expected case where an increased probability that the EU is soft reduces the government's chances of winning and thus increases the chances of entry with SBCs, does not apply for all parameter constellations. In particular, if the EU is perceived as relatively soft in the sense of $p>\hat{p}$ then if sufficiently many enlargement rounds are planned $(i(b))$ a further increase in EU softness benefits the government, hence making it more likely that the government's favorite outcome will occur. By increasing the softness of the EU, the government has an increased risk that when unveiling the information regarding the EU type, the country may in fact be permitted to enter with SBCs. Hence the government's willingness to wait increases sufficiently as a reaction to an increased probability that the EU is soft, such that the firms' willingness to wait will be outpaced. ${ }^{18}$ The possibility that such a scenario may occur depends critically on the value of $\hat{p}$. The value of $\hat{p}=1+\frac{\alpha}{2 \sigma}-\frac{\beta}{2 \tau}$ is only within the parameter range, i.e. $1>\hat{p}>0$ if $\frac{\alpha+2 \sigma}{\sigma}>\frac{\beta}{\tau}>\frac{\alpha}{\sigma}$.

\footnotetext{
${ }^{18}$ In terms of the official EU position only case (b) in proposition 2 (i) applies, since officially there is no limitation on the number of future enlargement rounds. Rather, each
} 
Corollary 1. If $\frac{\alpha+2 \sigma}{\sigma}<\frac{\beta}{\tau}$, then $\hat{p}<0$ and hence we are in case i) in proposition 2. If $\frac{\beta}{\tau}<\frac{\alpha}{\sigma}$, then $\hat{p}>1$ and hence we are in case ii) in proposition 2.

Thus for a sufficiently large $\sigma$, the scenario of case $i$ ) in proposition 2 will always exist, such that for a low enough risk of closing the door, $\phi$, an increase in EU softness will in fact improve the chances that candidates enter with an HBC. Yet, this case might be considered rather unusual, in the sense that it says that the applicant government is very eager to obtain HBCs while the $\mathrm{EU}$ is not.

\section{The effects of closing the door}

Next the effect of altering the probability that the game may end $\phi$ stems also both from reactions in $\bar{t}_{g}$ and $\bar{t}_{f}$. Again for simplicity we assume equal rates of time preferences $\rho_{g}=\rho_{f}=\rho$ and calculate $\frac{\partial h}{\partial \phi}$ (see separate Appendix) and obtain the following result (for proofs, see separate Appendix):

Proposition 3. There exists a critical $p^{c}<1$ such that for all cases where $p>p^{c}$ :

i) If $\frac{\alpha+\sigma}{\alpha}>\frac{\beta}{\beta-\tau}$, i.e. the government's win/lose ratio is greater than the firms' win/lose ratio, then $\frac{\partial h}{\partial \phi}<0$, i.e. an increase in the probability of no further enlargement rounds harms the government's chances of winning.

ii) If $\frac{\alpha+\sigma}{\alpha}<\frac{\beta}{\beta-\tau}$, i.e. the government's win/lose ratio is less than the firms' win/lose ratio, then $\frac{\partial h}{\partial \phi}>0$, i.e. an increase in the probability of no further enlargement rounds improves the government's chances of winning.

In plain words, proposition 3 says that the player that has more at stake (i.e. the larger win/lose ratio) is hurt more severely by a higher risk of closing the door, i.e. is more likely to lose the game. One immediate policy conclusion that can be derived from this finding is that an EU that suffers from a relatively soft image can only improve the chances of applicants displaying budget discipline by limiting the number of enlargement rounds if the government of the applicant country has less at stake than the firms. Otherwise, keeping the enlargement process open (reducing $\phi$ ) is the superior option.

applicant will be allowed to enter as soon as judged to be ready on grounds of its merits. However, in reality - given the fixed costs (e.g. reorganising the EU institutions) that each enlargement round causes - it appears that $\phi$ is larger than zero. Further, as will be shown below, an increase in $\phi$ need not strengthen the government's position. 
However, proposition 3 applies only for high levels of $p$. In order to be able to derive results for low levels of $p$ one has to simplify the analysis further by assuming $\rho_{g}=\rho_{f}=0$. One can now state:

Proposition 4. There exists a critical $p^{k}>0$ such that when $p<p^{k}$ :

i) for $\phi \rightarrow 1$ a further increase in $\phi$ reduces the government's chances of winning, i.e. $\frac{\partial h}{\partial \phi}<0$.

ii) for $\phi \rightarrow 0$

(a) $\frac{\partial h}{\partial \phi}>0$ if $\frac{\alpha+\sigma}{\sigma}>\frac{\beta-\tau}{\tau}$, i.e. the government's chances of winning are improved when the risk of closing the door rises.

(b) $\frac{\partial h}{\partial \phi}<0$ if $\frac{\alpha+\sigma}{\sigma}<\frac{\beta-\tau}{\tau}$, i.e. the government's chances of winning are reduced when the risk of closing the door rises.

For proof see separate Appendix. Thus in terms of policy, proposition 4 says that, assuming the EU is interested in aiding the SBC hardening process in the applicant countries and assuming that the EU is perceived as tough $(p$ low), then a policy of closing the door can only be beneficial if we are in case (ii) (a), i.e a situation where $\frac{\alpha+\sigma}{\sigma}>\frac{\beta-\tau}{\tau}$, which says that the government's ratio of winning over the gain from winning must be larger than the firms' ratio of losing over the cost of losing. Only in such a situation does closing the door promote the regime switch towards HBCs. In all other cases, keeping the enlargement process open (reducing $\phi$ ) will help the applicants to harden SBCs.

To sum up, our model predicts that a conditionality for membership in the EU can increase the probability that a country will implement an HBC. The model does not, however, state that accession candidates will necessarily enforce HBCs in all cases. The outcome of the war of attrition depends on whether enterprises or the government have more at stake in the enlargement process. Moreover, a tough application of the accession criteria by the EU and limiting the number of future enlargement rounds will only under certain parameter constellations aid the budget constraint hardening process.

\section{Empirical evidence}

Our theoretical examination of the effects of outside conditionality on SBCs arrives at various results and scenarios which cannot possibly all be tested empirically. Instead we focus on the underlying hypothesis that the outside conditionality imposed by the status of being an accession candidate to the 
EU has resulted in a hardening of SBCs. As introduced in Section 2, the SBC syndrome can manifest itself in several ways: injection of refinancing or credit from financial institutions or the state, direct budgetory subsidies, a reduction of taxes, a renegotiation of administrative prices, tax-, wage-, and interenterprise arrears, etc. The crucial point of the SBC syndrome is that these transfers are paid ex post, i.e. after the firm's losses have been observed, in order to bail out loss-making enterprises (Kornai, 1980; Goldfeld and Quandt, 1988, 1990; Schaffer, 1989; Dewatripont and Maskin, 1995).

Since the soft budget syndrome is characterised by ex post payments of transfers rather than by the existence of governmental subsidies and other transfer payments per se, it is not a straightforward matter to measure SBCs. Budgetary subsidies deriving from price controls can hardly be separated from financial support to inefficient and otherwise loss-making enterprises, such that the volume of subsidies is not appropriate to measure the SBC syndrome. A possible indicator used in the literature are tax arrears, although firms may lobby for tax arrears even if they are not in financial distress (Schaffer, 1998). Moreover, differences in reporting and measurement makes cross-country comparisions of tax arrears difficult. Another measure for SBCs which is applied in the empirical literature is the volume of credits classified as bad by the banking system. The banking system is indeed one of the key channels by which loss-making firms are subsidised in transition countries. Unfortunately, bad loans are neither necessary nor sufficient evidence of SBCs (Schaffer, 1998): on the one hand, financial institutions may hide soft loans in their balance sheets and roll over debts when they are due, while on the other hand banks may increasingly report non-performing loans inherited from the past in their balance sheets without providing fresh money to loss-making firms. Furthermore, interenterprise arrears are also a problematic measure of SBCs, since they do not necessarily imply the softening of financial discipline of the enterprise sector. Moreover, the empirical evidence shows that the levels of interenterprise arrears in many transition countries have been stable over time and in fact comparable to the levels observed in western market economies (Belka et al. 1995; Bonin and Schaffer, 1995; Alfandari and Schaffer, 1996; Schaffer, 1998).

Another strand of the empirical literature refers to business account data of firms in transition countries. Again, several conceptional problems plague the empirical analysis. According to the definition of the SBC, we are looking for evidence that fresh money is provided to firms even if losses are persistent. This involves several problems of measurement: first, even if an enterprise has made losses in the past, there may be the expectation of large profits in the future, which makes it rational to provide additional financial resources for a lender which attempts to enforce hard budget constraints. Second, firms 
may be economically viable but persistently loss-making if they have a large debt burden, i.e. if the debt service exceeds operating profits. The existence of these firms is again no evidence of SBCs, since debts may increase in this case without an injection of fresh money into the enterprise. Moreover, there are several problems of measuring profits by historical cost accounting in an environment with inflation (for a detailed discussion see Schaffer, 1998).

Not surprisingly, given these conceptual problems, the empirical literature on the SBC syndrome in transition countries yields inconclusive and even contradictory results. As an example, the EBRD transition report ranks Belarus below all accession candidates with respect to enterprise reform and enforcement of financial discipline in the enterprise sector (EBRD, 2001, p. 14), while Carlin et al. (2001) find on the basis of a comprehensive survey of 3,300 firms in 25 transition countries that the enforcement of HBCs is comparable in Belarus to the enforcement observed in the Czech Republic and Slovenia. Moreover, many indicators of SBCs are only available for few time-series observations, rendering an analysis of the impact of candidate status impossible.

Against this background, we take a different route in measuring SBCs here. Instead of measuring them directly, we focus on the consequences of SBCs for the behaviour of enterprises. Specifically, we examine whether or not candidate countries display (i) a long term lower labour to output ratio and (ii) a faster adjustment of labour demand to output shocks. The advantage of this approach is that macroeconomic data on output and employment which allow cross-country and cross-time comparisions are easily available. The underlying hypothesis that soft budget constraints result in excess labour demand and less adjustment of employment to economic shocks is well established in the SBC literature. Starting with Kornai (1979, 1980), labour hoarding has been recognised as one of the key features of the SBC syndrome. Enterprises that expect a bail-out tend to hire more labour than enterprises that operate in an environment with HBCs. Consequently, one expects that economies where SBCs persist tend to produce more labour intensively, and tend to adjust their labour force less swiftly to demand shocks than their counterparts with HBCs. More formally, Hillman et al. (1987) show that the factor demand of firms increases if output prices are uncertain and firms expect ex ante a bailout in case of unfavourable output prices. ${ }^{19}$ Similarly,

\footnotetext{
${ }^{19}$ Hillman et al. (1987) also show that if the firm's capital decision - and not just the labour decision - can be revised in response to the bail out probability, if firms can actually be liquidated, and if the probability of bail-out reacts only weakly to the amount of labour employed by the firm, then there exist parameter constellations where a high probability of government bail-out has an ambiguous effect on the relative labour intensity in production.
} 
Goldfeld and Quandt $(1988,1990)$ demonstrate in a series of models that soft transfers trigger a rising factor demand of firms, in particular a rising labour demand. Moreover, there exist a number of models which underline that the main motive for granting soft transfers by a paternalistic government is to induce firms to maintain higher levels of employment, which results again in excess labour demand (e.g. Boycko et al., 1996). ${ }^{20}$ Case studies at the enterprise level in transition countries in the 1990s indeed provide ample evidence that the hardening of budget constraints is associated with the shedding of excess labour and increasing labour productivity. ${ }^{21}$

However, it is worth noting that a caveat applies to our approach: other factors than the hardening of budget constraints may affect labour productivity and the adjustment of employment to output shocks: international specialisation patterns may trap countries in a state of low labour productivity, and rigid labour market institutions may hinder the adjustment of employment to output shocks even if hard budget constraints are enforced in the economy. Nevertheless, we believe that in case of the transition countries, where excess labour demand was widespread in the beginning of the transition process, rising labour productivity and the adjustment of employment to economic shocks are the best macroeconomic indicators available for cross-country and cross-time comparisons of the hardening of budget constraints.

The remainder of this Section is organised as follows: First, we motivate our empirical examination of the SBC syndrome by a simple model of labour demand - similar to Hillman et al. (1987) - where firms face soft budget constraints. From this we derive our specification of the estimation equation. Second, we describe the data base. Third, we present the estimation results.

\subsection{Model specification}

Consider first the standard case of the labour demand of a risk-neutral firm operating in an environment with price (demand) uncertainty and under HBCs. The conditions in the product market are characterised either by a favorable state with a high price level $\bar{P}$, which is expected with probability $p$ in each period, and an unfavorable state with a low price $\underline{P}$, which occurs

\footnotetext{
${ }^{20}$ In fact even within the Dewatripont and Maskin (1995) model one can argue that the 'slow and bad' projects - which require refinancing - do not just absorb more capital for a given amount of final output, but also consume more of all other inputs, including labour.

${ }^{21}$ See for Poland Pinto et al. 1993; for Russia de Boisseau et al. 1995, and Pinto et al. 2000; for Romania Abdelati and Claessens, 1996, and Coricelli and Djankov, 1998; and for Bulgaria Djankov and Hoekman, 2000, and Claessens and Peters, 1997. Furthermore, see the comprehensive surveys of Carlin et al., 2001 and Frydman et al., 2000.
} 
with probability $1-p$. Thus the expected price is

$$
P^{e}=p \bar{P}+(1-p) \underline{P} .
$$

For such a firm, the expected profits are $\pi^{e}=P^{e} Y-w L-r K$ where $Y$ is output and $L$ and $K$ denote labour and capital respectively; and $w$ and $r$ denote the wage and interest rate. Assuming that the firm is a price-taker and has to fix its labour input and production at the beginning of each period - i.e. before the actual price on its product market is revealed - then the profit maximising labour demand, given a short-run fixed capital stock and a standard Cobb-Douglas production function, $Y=A L^{a} K^{1-a}$, is:

$$
L_{h}^{*}=\left(\frac{a A P^{e}}{w}\right)^{\frac{1}{1-a}} K=\frac{a}{w} P^{e} Y=\lambda_{h} Y
$$

Thus, $\lambda_{h}$ denotes the optimal labour-to-output ratio in the case of HBCs.

Consider now the same firm operating under an SBC. The firm still maximises profits, but it can expect to receive a subsidy $S$ in the unfavorable state $1-p$. The literature contains many variants of the SBC phenomenon, but in one way or the other, the size of these subsidies is positively correlated to the size of the firms, i.e. to the output and employment of the firm (e.g. Carlin et al., 2001; Shleifer and Vishny, 1994; Hillman et al., 1987). Formally, we assume that the SBC transfer $S(Y, L)$ is a function of output and labour, where $S(0,0)=0$ and $\frac{\partial S}{\partial Y}, \frac{\partial S}{\partial L}, \frac{\partial Y}{\partial L}>0$. With an SBC, the firm's profit function becomes

$$
\pi^{e}=P^{e} Y+(1-p) S(Y, L)-w L-r K
$$

maximisation of which results in the optimal labour input

$$
L_{s}^{*}=\frac{a}{w-(1-p) \frac{d S}{d L}} P^{e} Y=\lambda_{s} Y .
$$

Thus $\lambda_{s}$ denotes the optimal labour-to-output ratio in the case of an SBC. Note that a well-defined solution of equation (9) requires that $w>(1-p) \frac{d S}{d L}$. Since the partial derivatives of $S(Y, L)$ are positive, and since $\frac{\partial Y}{\partial L}$ is positive, we have $d S / d L>0$ and can state:

$$
\lambda_{s}>\lambda_{h}
$$

Thus, the optimal ratio of the labour force to output in an SBC enterprise is larger than that of its HBC counterpart. This illustrates the intuitively compelling result that an excessive level of employment can be taken as an indicator of SBCs. 
To determine the equilibrium labour demand, we have so far assumed that the development of prices follows a stationary process, where the probability of a high price and the counter-probability of a low price are the same in each period. This is hardly a realistic description of real-world processes, where price levels vary widely such that $P_{t}^{e} \neq P_{t-1}^{e}$. As a consequence, firms have to adjust output and their labour force to changes in expected price levels. Since hiring and firing involves costs, the firm will not immediately adjust its labour force to the level desired in the long-run equilibrium. A simple way to specify the dynamics of such a system with adjustment costs is a partial adjustment model,

$$
L_{t}-L_{t-1}=\gamma\left(L_{t}^{*}-L_{t-1}\right), \quad 0<\gamma<1,
$$

where the actual change in the labour force is only a fraction of the desired change, and the speed of adjustment is determined by the parameter $\gamma$. Thus the parameter $\gamma$ measures the costs of adjustment relative to the costs of being in disequilibrium. Since SBCs - as shown above - reduce ceteris paribus the costs of being in disequilibrium, we must have:

$$
\gamma_{h}>\gamma_{s}
$$

whereby $h$ and $s$ denote the situation under hard and soft budgets respectively. Substituting (8) and (9) respectively for $L^{*}$ and bringing the lagged dependent on the right hand side yields

$$
L_{t}=\gamma_{j} \lambda_{j} Y_{t}+\left(1-\gamma_{j}\right) L_{t-1}, \quad j \in\{h, s\},
$$

which forms the basis for the specification of our estimation model.

\subsection{The data}

For the empirical analysis we pool aggregate employment and output data from 21 transition countries in the period 1990-99. Our sample comprises the ten accession candidates to the $\mathrm{EU}^{22}$ and 11 non-candidate countries ${ }^{23}$. Presumably, all these countries were characterised by a regime of SBCs as a legacy from central planning at the beginning of the transition process. Subsequently to the formulation of the pre-accession strategy of 1994, candidate status was officially granted to the accession candidates. This allows us to use the variance of economic behavior in the accession countries both

\footnotetext{
${ }^{22}$ See footnote 2 .

${ }^{23}$ Azerbaijan, Armenia, Belarus, Croatia, Georgia, Kyrgyz Republic, Kazhakstan, FYR Macedonia, Russian Federation, Ukraine, Uzbekistan.
} 
before and after candidate status was granted - i.e. pinpointing the time period when outside conditionality should kick in -, as well as the variance of economic behavior across candidate and non-candidate countries for the empirical analysis. However, our data base is, with ten time-series observations, rather small, and adjustment to the new institutional and economic environment is not yet completed in the transition economies.

We use real GDP and total employment data from the UN/ECE Common Database (UN/ECE, 2002, Appendix Tables B.1 and B.5), which are derived from national statistics and statistics of the CIS, as output and employment variables. Both variables are used in index form, in order to control for initial differences in labour productivity across countries. Both indexes are denominated to the year 1989 .

\subsection{Estimation results}

On basis of the partial adjustment model in (12) we estimate the equation

$$
\begin{array}{r}
L_{i t}=\alpha+\beta_{1} Y_{i t}+\beta_{2} D_{i t}^{*} Y_{i t}+\beta_{3} L_{i, t-1}+\beta_{4} D_{i t}^{*} L_{i, t-1}+ \\
\beta_{5} \text { Trend }_{t}+\beta_{6} D_{i t}^{*} \text { Trend }_{t}+\beta_{7} D_{i t}+u_{i t},
\end{array}
$$

where $L_{i t}$ is the aggregate employment index, $\alpha$ a constant, $Y_{i t}$ aggregate output index, $D_{i t}$ a dummy variable which has a value of 1 if country $i$ has a candidate status at time $t$, and zero otherwise, Trend $_{t}$ a time trend, and $u_{i t}$ the disturbance term. The subscript $i$ denotes the $i$ th country $(i=1, \ldots, 21)$, and the subscript $t$ the $t$ th year $(t=1, \ldots, 10)$.

Thus, we complemented the model in (12) by a time trend, which should capture other factors which persistently change the labour-to-output ratio such as labour augmenting technological progress. For the countries which do not possess a candidate status in period $t$, we can identify the structural parameters of the model $\gamma_{\text {non }}$ and $\lambda_{\text {non }}$ from the estimated coefficients as $1-\beta_{3}$ and $\beta_{1} /\left(1-\beta_{3}\right)$, respectively. We follow the usual convention in assuming that the disturbance term is specified as a two-way error-component model (Hsiao, 1996), i.e. that $u_{i t}=\mu_{i}+v_{t}+\nu_{i t}$ where $\mu_{i}$ denotes the country-specific fixed effect, $v_{t}$ a year-specific fixed effect, and $\nu_{i t}$ is white noise. This can be justified by country specific characteristics and common macroeconomic shocks. We started by estimating the model with the full set of time and country dummies and then tested for their significance jointly as well separately.

For the countries that possess candidate status, the parameters $\gamma_{\text {can }}$ and $\lambda_{\text {can }}$ are calculated as $\left(1-\beta_{3}-\beta_{4}\right)$ and $\left(\beta_{1}+\beta_{2}\right) /\left(1-\beta_{3}-\beta_{4}\right)$, respectively. Thus, if $\beta_{4}<0$, the adjustment parameter $\gamma_{c a n}>\gamma_{\text {non }}$, and, hence, 
the speed of adjustment is higher in the candidate countries. The interpretation of the coefficient $\beta_{2}$ is less straightforward: if $\beta_{2}<0$, and if $\beta_{4}<0$, too, then $\lambda_{\text {can }}<\lambda_{\text {non }}$, and, hence, the long-run ratio of employment with respect to output is smaller in the candidate countries than in the non-candidate countries. However, if $\beta_{4}<0$, even a zero or positive value of the coefficient $\beta_{2}$ can yield a $\lambda_{\text {can }}<\lambda_{\text {non }}$. We therefore present the implicit values of the structural parameters together with the estimation results.

Table 2: Pooled Estimation Results ${ }^{1,2}$ of Partial Employment Adjustment Model

\begin{tabular}{|c|c|c|c|c|c|c|c|c|}
\hline$Y_{i t}$ & $D_{i t}{ }^{*} Y_{i t}$ & $L_{i, t-1}$ & $D_{i t}{ }^{*} L_{i, t-1}$ & Trend & $D_{i t} *$ Trend & $D_{i t}$ & Const. & $R^{2}$ \\
\hline \multicolumn{9}{|c|}{ A. Total Sample (21 countries), 1990-9933,4 } \\
\hline $\begin{array}{r}0.116 \\
(4.86)\end{array}$ & $\begin{array}{r}-0.060 \\
-(2.11)\end{array}$ & $\begin{array}{r}0.839 \\
(26.11)\end{array}$ & $\begin{array}{r}-0.158 \\
-(2.52)\end{array}$ & $\begin{array}{r}0.313 \\
(2.42)\end{array}$ & $\begin{array}{r}-0.953 \\
-(3.69)\end{array}$ & $\begin{array}{r}25.346 \\
(4.15)\end{array}$ & $\begin{array}{r}6.900 \\
(1.51)\end{array}$ & 0.97 \\
\hline \multicolumn{9}{|c|}{ B. Candidate countries (10 countries), 1990-9933,5 } \\
\hline $\begin{array}{r}0.206 \\
(7.76)\end{array}$ & $\begin{array}{r}-0.122 \\
-(4.01)\end{array}$ & $\begin{array}{r}0.804 \\
(10.06)\end{array}$ & $\begin{array}{r}-0.131 \\
-(1.77)\end{array}$ & $\begin{array}{r}0.529 \\
(1.43)\end{array}$ & $\begin{array}{r}-1.235 \\
-(3.12)\end{array}$ & $\begin{array}{r}29.201 \\
(3.42)\end{array}$ & $\begin{array}{r}-0.071 \\
-(.01)\end{array}$ & 0.89 \\
\hline $\begin{array}{l}1 \text { Number } \\
2 \text { All regr } \\
3 \text { LSDV r } \\
4 \text { Implicit } \\
5 \text { Implicit }\end{array}$ & $\begin{array}{l}\text { in parentl } \\
\text { sions inclu } \\
\text { ression wi }\end{array}$ & $\begin{array}{l}\text { sis denote } \\
\text { e country } \\
\text { Prais-W } \\
\text { lues: } \gamma_{n o} \\
\text { lues: } \gamma_{n o}\end{array}$ & $\begin{array}{l}\text {-statistics. } \\
\text { lummies. } \\
\text { sten heterosce } \\
=0.161, \gamma_{\text {can }} \\
=0.196, \gamma_{\text {can }}\end{array}$ & $\begin{array}{l}\text { asticity } \\
=0.369, \\
=0.327\end{array}$ & $\begin{array}{l}\text { crected stand } \\
\text { on }=0.720, \lambda \\
\text { on }=1.020, \lambda\end{array}$ & $\begin{array}{l}n=0.176 \\
n=0.250\end{array}$ & & \\
\hline
\end{tabular}

\section{Results for the total sample}

We begin to estimate equation (13) for the total sample. Although country and time dummies were highly significant jointly, it turns out that the time dummies are not significant when tested separately. ${ }^{24}$ Consequently, we present here our estimates with the significant country-specific effects only. As shown in Section A of Table 2, both the coefficients of the interaction dummies of the candidate status with the lagged employment variable

\footnotetext{
${ }^{24}$ Both country and time dummies are jointly significant with an observed $F$-statistic of 4.21 , which has a $p$-value of well below one percent under the null distribution of $F(29,172)$. The observed $F$-statistic for the significance of the time dummies (given the existence of the country-specific effects) is 1.36 , which has a $p$-value of above 5 per cent under the null distribution of $F(9,172)$, and the observed $F$-statistic for the significance of the country dummies is 5.30, which has a $p$-value of well above 1 per cent under the null distribution of $F(20,172)$. These results emphasize the importance of country-specific effects in the partial employment adjustment equation.
} 
and the output variable have a negative sign and are statistically significant, which implies that:

(i) the estimated adjustment parameter $\gamma_{c a n}$ is significantly larger than $\gamma_{\text {non }}$, i.e. countries which have a candidate status at time $t$ adjust their labour force to equilibrium levels more quickly,

(ii) the estimated parameter $\lambda_{\text {can }}$, which determines the ratio of employment to output in the long-run, is significantly below $\lambda_{\text {non }}$, i.e. countries which possess a candidate status at time $t$ tend to have a lower employment-to-output ratio.

Thus, these estimates confirm the hypothesis that accession candidates have lower labour-to-output ratios and a higher speed of adjusting employment to output shocks than non-candidate countries. However, it is worth noting that the values of the long-run coefficient $\lambda_{\text {can }}$ seem to be implausibly low. This is perhaps a hint that the results suffer from some estimation bias, a problem which is discussed below.

\section{Does candidate status affect the SBC problem?}

One possible objection to estimating equation (13) is that the development of the output and employment variables may have affected the decision to grant the candidate status. In order to address the problem of a possible endogeneity, we conducted two alternative experiments: first, we estimated equation (13) for accession candidate countries only, in order to examine whether we can observe a change in economic behaviour within the same group of countries before and after candidate status was granted, i.e. before and after EU conditionality was set. Second, we split the sample into two time periods, 1990-94 and 1995-1999, in order to examine whether we observe a difference in economic behavior between the countries that become candidates later and the non-candidate countries in the periods before and after candidate status was granted.

As can be seen in Section B of Table 2, the results of the candidate country sample are close to those of the total sample: we observe again that both the coefficients of the interaction dummies of the candidate status with the lagged employment variable and the output variable have a negative sign and are still statistically significant. ${ }^{25}$ Thus, the regression based on the (later) candidate country sample shows again that:

\footnotetext{
${ }^{25}$ The coefficient for the interaction dummy with the lagged employment variable is statistically significant only at the 10 per cent level.
} 
(i) granting the candidate status is associated with a higher speed of adjustment

(ii) granting the candidate status is associated with a lower labour-tooutput ratio relative to the period before the countries become accession candidates.

\section{Country group differences pre and post enlargement option}

To further investigate the mechanics of the outside conditionality, consider the following. If the EU had only started membership negotiations with those countries that already had an HBC regime, than this altered performance must already be observable prior to the official start of membership negotiations and imposition of EU conditionality. Hence we compare the situation in candidate and non-candidate countries in the first and second half of the 1990s.

Table 3: Pooled Estimation Results ${ }^{1,2}$ of Partial Employment Adjustment Equation, 1990-94 and 1995-99

\begin{tabular}{llllllll}
\hline \hline$Y_{i t}$ & $D_{i}{ }^{*} Y_{i t}$ & $L_{i, t-1}$ & $D_{i}{ }^{*} L_{i, t-1}$ & Trend $_{t}$ & $D_{i}{ }^{*}$ Trend $_{t}$ & Const. & $R^{2}$ \\
\hline
\end{tabular}

\begin{tabular}{|c|c|c|c|c|c|c|c|}
\hline \multicolumn{8}{|c|}{ A. Total Sample (21 countries), 1990- $94^{3,4}$} \\
\hline $\begin{array}{c}0.222 \\
2.13)\end{array}$ & $\begin{array}{c}0.004 \\
(.04)\end{array}$ & $\begin{array}{r}0.775 \\
(6.9)\end{array}$ & $\begin{array}{r}-0.086 \\
-(.55)\end{array}$ & $\begin{array}{c}0.962 \\
(1.08)\end{array}$ & $\begin{array}{l}-0.792 \\
-(.77)\end{array}$ & $\begin{array}{r}1.980 \\
(.12)\end{array}$ & 0.95 \\
\hline \multicolumn{8}{|c|}{ B. Total Sample (21 countries), 1995-9933 } \\
\hline $\begin{array}{r}0.202 \\
(4.1)\end{array}$ & $\begin{array}{r}-0.126 \\
-(1.87)\end{array}$ & $\begin{array}{r}0.624 \\
(11.08)\end{array}$ & $\begin{array}{r}-0.029 \\
-(.2)\end{array}$ & $\begin{array}{r}-0.226 \\
-(1.46)\end{array}$ & $\begin{array}{r}-0.423 \\
-(1.78)\end{array}$ & $\begin{array}{r}28.199 \\
(4.23)\end{array}$ & 0.99 \\
\hline $\begin{array}{l}\text { LSDV } \\
\text { Implic } \\
\text { Implic }\end{array}$ & & lues: $\gamma$ & $\begin{array}{l}1 \\
225, ? \\
376, ?\end{array}$ & $\begin{array}{l}=0.0 \\
=0.4\end{array}$ & $\begin{array}{l}984, \lambda_{c c} \\
536, \lambda_{c d}\end{array}$ & $\begin{array}{l}\text { rrors. } \\
=0.727 . \\
=0.188 .\end{array}$ & \\
\hline
\end{tabular}

Table 3 reports the results from the estimation of a variant of equation (13):

$$
\begin{array}{r}
L_{i t}=\alpha+\beta_{1} Y_{i t}+\beta_{2} D_{i}^{*} Y_{i t}+\beta_{3} L_{i, t-1}+\beta_{4} D_{t}^{*} L_{i, t-1}+ \\
\beta_{5} \text { Trend }_{t}+\beta_{6} D_{i}^{*} \text { Trend }_{t}+\beta_{7} D_{i}+u_{i t},
\end{array}
$$

where the dummy variable $D_{i}$ has the value of 1 , if the country belongs to the group of (later) accession candidates, and 0 otherwise. The disturbance 
term is specified as $u_{i} t=\mu_{i}+\nu_{i t}$, since again the country-specific effects have turned out to be highly significant. ${ }^{26}$ Interestingly enough, the estimate in Section A of Table 3 shows that both candidate dummies turned out to be statistically insignificant in the pre-candidate period. Moreover, the regression results reported in Section B of Table 3 show that the interaction dummy with the output variable becomes statistically significant (at the 10 percent-level) after the candidate status has been granted. Thus we can - with the appropriate caution, given our sample size of five time series observations - state:

(i) there is no observable significant difference of employment adjustment between the later candidate and the non-candidate countries in the early 1990s.

(ii) the labour-to-output ratio in the candidate countries falls relative to the non-candidate countries after the candidate status has been granted (post-1995).

Thus the candidates for accession to the EU changed their economic behavior with respect to labour hoarding and the adjustment of employment to output shocks after candidate status was granted. However, the dynamic fixed effect estimator that we have applied is subject to a simultaneous equation bias due to the presence of the lagged dependent variable (Nickell, 1981; Kiviet, 1995). Although the fixed effect estimator avoids the inconsistency which arises if the country-specific effects are correlated with the other explanatory variables, serial correlation of the disturbance terms in equations (13) and (14) introduces endogeneity between the $\nu_{i t}$ and the lagged employment variable. The estimation bias declines with the time dimension of the panel, but it may be substantial in the case of our small sample (Judson and Owen, 1999). In Appendix 1 we therefore present a consistent GMM estimator, which largely confirms the results of our fixed effects estimations.

\section{Conclusions and policy implications}

This paper has theoretically and empirically examined the question of whether or not the conditionalities that the EU has imposed on applicant countries in the process of eastern enlargement - e.g. the Copenhagen criteria and the monitoring of the progress towards compliance with the acquis

\footnotetext{
${ }^{26}$ The observed $F$-statistic in regression A and B for the significance of the country dummies is 2.70 and 4.17 , respectively, which yields in both cases a $p$-value of well above 1 per cent under the null distribution of $F(20,78)$.
} 
communautaire - can help the candidate countries to tackle the persisting domestic SBC problem. We understand the SBC syndrome as a state of regime with institutions that result in an inability of the government (or in fact banks) to credibly commit to enforcing financial discipline on the enterprise sector ex post. In case of countries which are trapped in such an SBC status quo, the shift towards institutions which could enable the government to enforce hard budget constraints may, however, be blocked by those who benefit from SBCs, e.g. the firms and their employees. Many observers of the enlargement process have argued that the prospect of EU membership which benefits both governments and firms - could challenge this stalemate in the balance of power in the applicant countries.

This fundamental reasoning is captured in our model, where the outside conditionality of the EU demands a regime shift towards HBCs. While firms hold the key to implementing HBCs by agreeing to the regime switch and complying with financial discipline, the government holds the key to negotiating EU membership. Hence both parties can hold each other hostage, i.e. firms and government play a waiting game in complying with HBCs and in negotiating the country into the EU. Furthermore, even though the EU has conditioned membership on the enforcement of HBCs, the actual toughness of the conditionality is uncertain. We use this war of attrition setting to study the impact of several policy parameters. Our central finding is that external conditionality can play an important role in resolving the domestic SBC issue, but need not necessarily do so. From our results a number of policy implications emerge:

First, a necessary condition for resolving the SBC syndrome via outside conditionality is that firms benefit more from EU membership than they lose from an enforcement of HBCs. Although it may seen fairly obvious, this result has important policy implications: the EU can increase the pressure on changing the domestic balance of power by raising the benefits from economic integration to the firms through e.g. full market access or complete dismantling of technical barriers for future members. ${ }^{27}$

Second, the perceived toughness of the EU conditions can - if believed to be strict enough - immediately resolve the domestic SBC problem. This is exactly the strategy that the Copenhagen Criteria and the Commission's annual progress reports pursued, namely, threatening the ultimate punishment of keeping out non-performing candidates.

Third, we also show that outside conditionality may be less powerful if

\footnotetext{
${ }^{27}$ This may explain why an outside conditionality imposed by the EU can turn out to be more successful than that of financial institutions like the IMF, where no more than governmental credits are at stake.
} 
the applicant's government is too eager to get the country into the EU, while firms have less at stake or are more patient. Again, the EU can increase the power of the outside conditionality by raising the benefits from integration for those who have to agree on the regime shift relative to those who want the integration anyway.

Fourth, a policy of direct compensation from the EU to the applicant countries' firms or sectors for the costs that stem from structural adjustment will strengthen the applicant governments' positions and thus the effectiveness of the imposed conditionality. In fact, this is exactly what the financial assistance programmes, designed in the pre-accession strategy and agreed upon in the 1994 European Council, were aiming at.

Fifth, our model shows that the opportunity of closing the door, i.e. limiting the number of future enlargement rounds, can aid the budget hardening process if the EU conditionality is perceived as relatively soft and if the firms have more at stake in the future membership than the government. In all other cases, keeping the enlargement process open will improve the effectiveness of outside conditionality.

Finally, some counter-intuitive results emerge as well: for example, we find that within our model for certain parameter constellations, a softening of EU conditionality (i.e. laxer enforcement) need not warrant victory of the firms in the war of attrition. On the contrary, faced with a softer EU, the government may become more hesitant to promote the application, i.e. the government fears that the country will actually be admitted despite the persisting SBC problem. Accordingly the governments willingness to wait and hence its chance to win the war of attrition - increases.

In the empirical part of the paper, we examine our underlying hypothesis on the impact of outside conditionality for 21 transition countries over a tenyear period. We base our estimations on the relationship between output and employment. We show in a micro framework that the labour-to-output ratio, and more importantly, the adjustment speed of labour demand to output shocks can be taken as indicators of the softness of budget constraints. We find that those transition countries that hold a membership option - i.e. are subject to the EU conditionality - have a lower long-run ratio of labour to output and display a swifter adjustment of labour demand to output shocks. Thus, in line with our theoretical model, our empirical results indicate that the imposed conditionality on future members of the EU does indeed yield a hardening of budget constraints.

To sum up: a beneficial impact of outside conditionality on SBC hardening in transition economies, which observers have associated with the soon-to-be-completed enlargement process of the EU, does exist. This paper has outlined the mechanics of such conditionality theoretically and 
verified its impact empirically. However, our approach can only serve as a first step towards understanding the role of external conditionalities on internal economic problems. Future research will have to continue to examine the phenomenon of the SBC and the impact and functioning of outside conditionalities. In particular, since ever more supranational organisations place conditions on national economic conduct, and since the soft budget constraint, despite its genesis in the context of socialist and transition economies, is by no means a phenomenon unknown to market economies. 


\section{Appendix 1}

\section{GMM estimations of the partial labour adjustment equation}

There are several methods of controlling for group-specific effects; see Anderson and Hsiao (1981), Arellano and Bond (1991), Arellano and Bover (1995), Ahn and Schmidt (1995) and Kiviet (1995). Here, we apply the one- and two-step GMM estimators proposed by Arellano and Bond (1991), which tend to perform better than the Anderson-Hsiao estimator with our sample size (Judson and Owen, 1991). The Arellano-Bond estimators assume that the error term is not serially correlated (tested below). Moreover, Arellano and Bond (1991) provide a Sargan-test for over-identifying restrictions.

Since models which incorporate interaction dummies with the lagged dependent variable cannot be used, we estimated for both country groups the pre- and post-candidate periods separately. The regression diagnostics in Table A1 show that the null hypothesis of valid over-identifying restrictions is not rejected by the Sargan-test in most regressions. Note that Arellano and Bond (1991) found evidence that the Sargan-test may over-reject the null of valid over-identifying restrictions in the presence of heteroscedasticity. For inference on model specification, the Sargan-test based on the two-step estimator is more appropriate in this case. Indeed, while the Sargan-test in the one-step regressions rejects the null of valid over-identifying rejections, it is not rejected in the two-step regression in Section B (Table A1). However, autocorrelation of the residuals is present in some cases. Note that the presence of first-order autocorrelation does not, in contrast to second-order autocorrelation, imply that the estimates are inconsistent. The two-step estimator increases the efficiency of estimation substantially, but may bias coefficients and the standard errors downwards. Although in our case coefficients and $t$-statistics between the one-step and the two-step regressions are rather similar, we recommend the one-step estimates for inference (Arellano and Bond, 1991).

Table A1 shows that the GMM estimators yield much lower coefficients in all samples for the lagged dependent variable, and, hence, higher values for the adjustment parameter $\gamma$. This is as expected in the literature (Kiviet, 1995, Judson and Owen, 1999). However, although the size of the structural parameters has changed relative to the LSDV-estimates, the GMM estimates support the general results of the paper: (i) a comparison of the periods before and after candidate status was awarded shows that the speed of adjustment has increased at least moderately, while the long-run labour-to-output ratio has fallen substantially (Sections A and B of Table A1); (ii) in the period after the candidate status was granted the speed of adjustment in the 
candidate countries is substantially above that of non-candidates, while the long-run ratio of labour to output is substantially below (Sections B and D of Table A1); (iii) in the period before candidate status was granted there is no clear pattern: the adjustment parameter in the later candidate countries is estimated to be higher than that of the non-candidates, but the long-run ratio of labour to output is also estimated to be higher in the later candidate countries compared to the non-candidates (Sections A and C of Table A1).

Table A1: Results of LSDV and GMM-Estimations of Labour Adjustment ${ }^{1}$

\begin{tabular}{llllllllll}
\hline \hline$Y_{i t}$ & $L_{i, t-1}$ & & $T_{t}$ & Const. & $R^{2}$ & Wald-test $^{2}$ & $\gamma$ & $\lambda$ \\
\hline
\end{tabular}

A. Candidate Countries, 1990-95

$\begin{array}{rrrrrrrrr}\text { LSDV }^{3} & 0.213 & 0.672 & 0.013 & 9.374 & 0.75 & - & 0.33 & 0.65 \\ & (6.31) & (7.63) & -(.03) & (.93) & & & & \\ \text { Arellano-Bond }^{4} & 0.280 & 0.549 & -0.236 & - & - & 458.70 & 0.45 & 0.62 \\ \text { (one-step) }^{(7.01)} & (3.4) & -(.37) & & & & & \\ \text { Arellano-Bond }^{5} & 0.261 & 0.576 & -0.267 & - & - & 25466.13 & 0.42 & 0.61 \\ \text { (two-step) } & (17.14) & (14.59) & -(1.74) & & & & & \end{array}$

B. Candidate countries, 1996-99

$\begin{array}{rrrrrrrrr}\text { LSDV }^{6} & 0.076 & 0.595 & -0.650 & 31.271 & 0.60 & & 0.41 & 0.19 \\ & (1.4) & (3.73) & -(2.64) & (2.26) & & & & \\ \text { Arellano-Bond }^{7} & 0.094 & 0.522 & -0.746 & - & - & 105.45 & 0.48 & 0.20 \\ \text { (one-step) }^{(2.35)} & (3.93) & -(4.09) & & & & & \\ \text { Arellano-Bond }^{8} & 0.129 & 0.486 & -0.791 & - & - & 583.57 & 0.51 & 0.25 \\ \text { (two-step) } & (2.71) & (5.75) & -(9.42) & & & & & \end{array}$

1 Partial Labour Adjustment Equation. Numbers in parentheses denote $t$-statistics; the LSDV regressions include country dummies.

$2 \chi^{2}(3)$-statistic for the Wald-test of the joint significance of the coefficients.

3 The $F(9,47)$-statistic for the joint significance of the country dummies: $3.93(\mathrm{Pr}>\mathrm{F}=0.0009)$.

4 The $\chi^{2}$-statistic for the Sargan test of over-identifying restrictions is $8.5\left(\operatorname{Pr}>\chi^{2}(14)=0.86\right)$; the $t$-statistics for the Arellano-Bond test of first- and second-order autocorrelation of the residuals is -1.46 and -0.22 , respectively.

5 The $\chi^{2}$-statistic for the Sargan test of over-identifying restrictions is $5.8\left(\operatorname{Pr}>\chi^{2}(14)=0.97\right)$; the $t$ statistics for the Arellano-Bond test of first- and second-order autocorrelation of the residuals is -1.26 and -0.5 , respectively.

6 The $F(9,37)$-statistic for the joint significance of the country dummies: $2.29(\operatorname{Pr}>\mathrm{F}=0.037)$.

7 The $\chi^{2}$-statistic for the Sargan test of over-identifying restrictions is $61.89\left(\operatorname{Pr}>\chi^{2}(29)=0.0004\right)$; the $t$-statistics for the Arellano-Bond test of first- and second-order autocorrelation of the residuals is -0.29 and 1.97 , respectively.

8 The $\chi^{2}$-statistic for the Sargan test of over-identifying restrictions is $8.61\left(\operatorname{Pr}>\chi^{2}(29)=0.9999\right)$; the $t$-statistics for the Arellano-Bond test of first- and second-order autocorrelation of the residuals is -0.02 and -1.91 , respectively. 
Table A1 (cont.):

$Y_{i t} \quad L_{i, t-1} \quad T_{t} \quad$ Const. $\quad R^{2} \quad$ Wald-test $^{2} \quad \gamma \quad \lambda$

C. Non-candidate countries, 1990-95

$\begin{array}{rrrrrrrrr}\text { LSDV }^{9} & 0.130 & 0.803 & 0.401 & 5.746 & 0.75 & - & 0.20 & 0.66 \\ & (2.05) & (9.53) & (.69) & (.44) & & & & \\ \text { Arellano-Bond } & 0.126 & 0.713 & 0.201 & - & - & 102.64 & 0.29 & 0.44 \\ \text { (one-step) }^{10} & (1.62) & (5.87) & (.3) & & & & & \\ \text { Arellano-Bond } & 0.120 & 0.700 & 0.260 & - & - & 1822.07 & 0.30 & 0.40 \\ \text { (two-step) } & (16.29) & (20.02) & (2.44) & & & & & \end{array}$

D. Non-candidate countries, 1996-99

\begin{tabular}{|c|c|c|c|c|c|c|c|c|}
\hline $\mathrm{LSDV}^{12}$ & $\begin{array}{r}0.202 \\
(3.5)\end{array}$ & $\begin{array}{r}0.624 \\
(9.03)\end{array}$ & $\begin{array}{r}-0.226 \\
-(1.31)\end{array}$ & $\begin{array}{r}22.707 \\
(3.39)\end{array}$ & 0.73 & 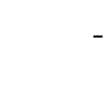 & 0.38 & 0.54 \\
\hline $\begin{array}{r}\text { Arellano-Bond }^{13} \\
\text { (one-step) }\end{array}$ & $\begin{array}{l}0.135 \\
(2.06)\end{array}$ & $\begin{array}{r}0.670 \\
(7.99)\end{array}$ & $\begin{array}{l}-0.082 \\
-(.45)\end{array}$ & - & - & 77.0 & 0.33 & 0.41 \\
\hline $\begin{array}{r}\text { Arellano-Bond } \\
\text { (two-step) }\end{array}$ & $\begin{array}{r}0.124 \\
(2.02)\end{array}$ & $\begin{array}{r}0.703 \\
(24.71)\end{array}$ & $\begin{array}{l}-(.40) \\
-0.067 \\
-(.73)\end{array}$ & - & - & 804.58 & 0.30 & 0.42 \\
\hline
\end{tabular}

9 The $F(9,47)$-statistic for the joint significance of the country dummies: $3.06(\operatorname{Pr}>\mathrm{F}=0.004)$.

10 The $\chi^{2}$-statistic for the Sargan test of over-identifying restrictions is $14.15\left(\operatorname{Pr}>\chi^{2}(14)=0.44\right)$; the $t$-statistics for the Arellano-Bond test of first- and second-order autocorrelation of the residuals is -2.25 and -1.47 , respectively.

11 The $\chi^{2}$-statistic for the Sargan test of over-identifying restrictions is $8.13\left(\operatorname{Pr}>\chi^{2}(14)=0.88\right)$; the $t$-statistics for the Arellano-Bond test of first- and second-order autocorrelation of the residuals is -1.41 and -0.92 , respectively.

12 The $F(10,41)$-statistic for the joint significance of the country dummies: $7.02(\operatorname{Pr}>\mathrm{F}=0.0000)$.

13 The $\chi^{2}$-statistic for the Sargan test of over-identifying restrictions is $28.6\left(\operatorname{Pr}>\chi^{2}(29)=0.49\right)$; the $t$-statistics for the Arellano-Bond test of first- and second-order autocorrelation of the residuals is -2.46 and 0.34 , respectively.

14 The $\chi^{2}$-statistic for the Sargan test of over-identifying restrictions is $9.08\left(\operatorname{Pr}>\chi^{2}(29)=0.99\right)$; the $t$-statistics for the Arellano-Bond test of first- and second-order autocorrelation of the residuals is -1.76 and 0.56 , respectively. 


\section{References}

Ahn, S.C. and P. Schmidt (1995), Efficient Estimation of Models for Dynamic Panel Data, Journal of Econometrics, Vol. 68, pp. 5-27.

Abdelati, W. and S. Claessens (1996), Losses, Financing, and Adjustment of State Enterprises in Romania, mimeo, World Bank.

Alfandari, G. and M.E. Schaffer (1996), "Arrear" in the Russian Enterprise Sector, in: Commander, S., Q. Fan and M.E. Schaffer (eds), Enterprise Restructuring and Economic Policy in Russia, Washington, DC: EDI/World Bank, pp. 87-139.

Anderson, T.W. and C. Hsiao (1981), Estimation of Dynamic Models With Error Components, Journal of the American Statistcical Association, Vol. 76, pp. 598-606.

Arellano, M. and S. Bond (1991), Tests of Specification for Panel Data: Monte Carlo Evidence and an Application to Employment Equations, Review of Economic Studies, Vol. 58, pp. 277-297.

Arellano, M. and O. Bover (1995), Another Look at the Instrumental Variable Estimation of Error Components Models, Journal of Econometrics, Vol. 68, pp. 29-52.

Alesina, A. and A. Drazen (1991), Why are Stabilisations Delayed?, American Economic Review, Vol. 81(5), pp. 1170-1188.

Bai, C. and Y. Wang (1998), Bureaucratic Control and the Soft Budget Constraint, Journal of Comparative Economics, Vol. 26, pp. 41-61.

Bai, C. and Y. Wang (1999), The Myth of the East Asian Miracle: The Macroeconomic Implications of Soft Budgets, American Economic Review, Vol. 89(2), pp. 432-437.

Belka, M., S. Estrin, M.E. Schaffer, I.J. Singh (1995), Enterprise Adjustment in Poland: Evidence from a Survey of 200 Private, Privatized, and StateOwned Firms, Centre for Economic Performance Discussion Paper No. 233, London: London School of Economics.

Bliss, C. and B. Nalebuff (1984), Dragon-slaying and ballroom-dancing: The private supply of a public good, Journal of Public Economics, Vol. 25, pp. $1-12$.

Bonin, J.P. and M.E. Schaffer (1995), Banks, Firms, Bad Debts and Bankruptcy in Hungary 1991-94, Centre for Economic Performance Discus- 
sion Paper No. 234, London: London School of Economics.

de Boisseau, C., D. Cohen, and G. de Pontbriand (1995), Russian Enterprises in Transition, CEPR Discussion Paper No. 1174.

Boycko, M., A. Shleifer, and R.W. Vishny, A Theory of Privatisation, (1996), Economic Journal, Vol. 106(1), pp. 309-19.

Carlin, W., S. Fries, M. Schaffer and P. Seabright (2001), Competition and Enterprise Performance in Transition Economies: Evidence from a Crosscountry Survey, CEPR Discussion Paper, No. 2840.

Claessens, S. and R.K. Peters (1997), State Enterprise Performance and Soft Budget Constraints: The Case of Bulgaria, Economics of Transitionm Vol. 5(2), pp. 305-22.

Coricelli, F. and S. Djankov (2001), Hardened Budgets and Enterprise Restructuring: Theory and an Application to Romania, Journal of Comparative Economics, Vol. 29(4), pp. 749-63.

Dewatripont, M. and E. Maskin (1995), Credit and Efficiency in Centralized and Decentralized Economies, Review of Economic Studies, Vol. 62, pp. $541-555$.

Djankov, S. and B. Hoekman (2000), Market Discipline and Corporate Efficiency: Evidence from Bulgaria, Canadian Journal of Economics, Vol. 33(1), pp. 190-212.

Dewatripont, M. and G. Roland (2000), Soft Budget Constraints, Transition, and Financial Systems, Journal of Institutional and Theoretical Economics, Vol.156, pp. 245-260.

EBRD (1999), Transition Report 1999, London: EBRD.

EBRD (2001), Transition Report 2001, London: EBRD.

European Commission (1998), Regular Report from the Commission on Czech Republics's progress Towards Accession, Brussels.

European Commission (2000), Regular Report from the Commission on Lithuania's progress Towards Accession, Brussels.

European Commission (2002a), Regular Report from the Commission on Bulgaria's progress Towards Accession, Brussels.

European Commission (2002b), Regular Report from the Commission on Romania's progress Towards Accession, Brussels. 
Frydman, R., C. Gray, M. Hessel and A. Rapaczynski (2000), The Limits of Discipline, Economics of Transition, Vol. 8(3), pp. 577-601.

Goldfeld, S.M. and R.E. Quandt (1990), Output Targets, the Soft Budget Constraint and the Firm under Central Planning, Journal of Economic Behavior and Organization, Vol. 14(2), pp. 205-22.

Goldfeld, S.M. and R.E. Quandt (1988), Budget Constraints, Bailouts and the Firm under Central Planning, Journal of Comparative Economics, Vol. $12(4)$, pp. 502-520.

Heinemann, F. (2000), Strategic Lessons from the Maastricht Criteria, Kredit und Kapital, Vol. 33(4), pp. 455-467.

Hendricks, K., A. Weiss and C. Wilson (1988), The war of attrition in continuous time with complete information, International Economic Review, Vol. 29, pp. 663-680.

Hillman, A.L., E. Katz, and J. Rosenberg (1987), Workers as Insurance: Anticipated Government Assistance and Factor Demand, Oxford Economic Papers, Vol. 39(4), pp. 813-20.

Huang, H. and C. Xu (1999), Institutions, Innovations and Growth, American Economic Review, Vol. 89(2), pp. 438-443.

Hsiao, C. (1986), Analysis of Panel Data, Cambridge, MA: Cambridge University Press.

Judson, R.A. and A.K. Owen (1999), Estimating dynamic panel data models: a guide for macroeconomists, Economic Letters, Vol. 65, pp. 9-15.

Kiviet, J. (1995), On Bias, Inconsistency and Efficiency of Various Estimators of Dynamic Panel Data Models, Journal of Econometrics, Vol. 68, pp. 53-78.

Kornai, J. (1979), Resource-constrained Versus Demand-constrained Systems, Econometrica, Vol. 47, pp. 801-819.

Kornai, J. (1980), Economics of Shortage, Amsterdam: North-Holland.

Kornai, J. (1998), The Place of the Soft Budget Constraint Syndrome in Economic Theory, Journal of Comparative Economics, Vol. 26, pp. 11-17.

Kornai, J. (2001), Hardening the Budget Constraint: The Experience of the Post-socialist Countries, European Economic Review, Vol.45, pp. 1573-1599.

Kornai, J., E. Maskin and G. Roland (2003), Understanding the Soft Budget Constraint, forthcoming, Journal of Economic Literature. 
Li, D. D. (1998), Insider Control and the Soft Budget Constraint: A Simple Theory, Economics Letters, Vol. 61(3), pp. 307-11.

Maskin, E. (1999), Recent Theoretical Work on the Soft Budget Constraint, American Economic Review, Vol. 89(1), pp. 421-426.

Maskin, E. and C. Xu (2001), Soft budget constraint theories: From centralisation to the market, Economics of Transition, Vol. 9(1), pp. 1-27.

Nickell, S. (1981), Biases in Dynamic Models with Fixed Effects, Econometrica, Vol. 49, pp. 1417-1426.

Perotti, E. (1998), Inertial credit and opportunistic arrears in transition, European Economic Review, Vol. 42, pp. 1703-1725.

Pinto, B., V. Drebentsov and A. Morozov (2000), Give Macroeconomic Stability and Growth in Russia a Chance. - Harden Budgets by Eliminating Non-Payments, Economics of Transition, Vol. 8(2), pp. 297-324.

Pinto, B., M. Belka, S. Krajewski and A. Shleifer (1993), Transforming State Enterprises in Poland: Evidence on Adjustment by Manufacturing Firms, Brookings Papers on Economic Activity, Vol. 1993(1), pp. 213-70.

Quian, Y. (1994), A Theory of Shortage in Socialist Economies Based on the Soft Budget Constraint, American Economic Review, Vol. 88(5), pp. 145-56.

Quian, Y. and C. Xu (1998), Innovation and Bureaucracy under Soft and Hard Budget Constraints, Review of Economic Studies, Vol. 66, pp. 156-64.

Quian, Y. and G. Roland (1998), Federalism and the Soft Budget Constraint, American Economic Review, Vol. 88(5), pp.1143-62.

Roland, G. and T. Verdier (2003), Law Enforcement and Transition, European Economic Review, Vol. 47(4), pp. 669-85.

Schaffer, M. (1989), The Credible-Commitment Problem in the CenterEnterprise Relationship, Journal of Comparative Economics, Vol. 13, pp. 359-382.

Schaffer, M. (1998), Do Firms in Transition Have Soft Budget Constraints? A Reconsideration of Concepts and Evidence, Journal of Comparative Economics, Vol. 26(1), pp. 80-103.

Shleifer, A. and R. Vishny (1994), Politicians and Firms, Quarterly Journal of Economics, Vol. 109(4), pp. 995-1025.

UN/ECE (2002), Economic Survey of Europe, No.1, 2002. 